\title{
積極的 COTSを導入した超小型推進系の開発と \\ S-310-36 号機による宇宙実証*1 \\ Development of Propulsion System for Microsatellite Based on Effective COTS, and Its Demonstration in S-310-36 Sounding Rocket Experiment
}

\author{
佐 原 宏 典*2 中須賀 真 一 $* 2$ \\ Hironori SAHARA and Shinichi NAKASUKA
}

Key Words : Propulsion, Cold Gasjet, COTS, S-310-36, Micro/Nano/Picosatellite

\begin{abstract}
The University of Tokyo, Kobe University and Vienna University of Technology conducted a set of experiments including large membrane "Furoshiki Satellite" extension and active phased array antenna operation in January 2006, by using ISAS/JAXA sounding rocket S-310-36, one of their purposes was to demonstrate a cold gasjet propulsion system for microsatellites which makes use of effective COTS. A series of verification tests concerning the propulsion were conducted on ground before the launch, and it resulted in confirmation of 70 seconds of specific impulse at $250 \mathrm{mN}$ of thrust with little leakage for 4 months and good resistance to vibration and shock environment of the launcher. Although specific impulse of the propulsion in orbit was not determined, the propulsion system worked very well and we acquired pressure history of its tank, and established the basis of moderate-priced propulsion system for microsatellites and are ready to salute the coming era of microsatellites equipped with propulsion.
\end{abstract}

記 号 の 説 明

$$
\begin{aligned}
P_{\mathrm{a}} & : \text { 雰囲気圧 } \\
P_{\mathrm{c}} & : \text { スラスタチェンバ圧 } \\
P_{\mathrm{e}} & : \text { ノズル出口圧 } \\
a & : \mathrm{DAU} \text { 加速度 } \\
M & : \mathrm{DAU} \text { 質量 } \\
v & : \mathrm{DAU} \text { 速度 } \\
A_{\mathrm{t}} & : \text { ノズルスロート面積 } \\
D_{\mathrm{t}} & : \text { ノズルスロート径 } \\
\varepsilon & : \text { ノズル開口比 } \\
T_{\mathrm{c}} & : \text { スラスタチェンバ温度 } \\
C_{\mathrm{F}} & : \text { 推力係数 } \\
\eta_{\mathrm{n}} & : \text { ノズル効率 } \\
c^{*} & : \text { 特性排気速度 } \\
\kappa & : \text { 比熱比 } \\
\Delta m & : \text { 推進剂質量流量 } \\
F & : \text { 推力 } \\
I_{\mathrm{SP}} & : \text { 比推力 } \\
\Delta V & : \text { 速度増分 } \\
\delta & : \text { Duty 比 } \\
T & : \text { 噴射時間 }
\end{aligned}
$$

*1 C 2007 日本航空宇宙学会

平成 19 年 4 月 5 日原稿受理

*2 東京大学大学院工学系研究科
1.は じめに

昨今では世界の各機関・大学において超小型衛星の開発 が盛んである1 4). 乥れらは質量 $1 \mathrm{~kg}$ の CubeSat クラス から大きいものは $100 \mathrm{~kg}$ 程度までの衛星であり，各種観測 や実験が行われ，また，計画されている．著者ら（東京大 学中須賀研究室) は 2003 年 6 月に世界初の CubeSat であ るXI-IV を打ち上げたことに始まり, 現在 2 機の CubeSat の運用を継続すると同時に次世代の本格的ミッション を遂行可能な超小型衛星の開発を行っている5).しかしな がら現在までに, 乥れらの超小型衛星に推進系が搭載され たことは非常に少なく ${ }^{68)}$, 姿勢制御は磁気トルカやホイー ルで行い, 軌道変更は通常行われていない . 推進系があれ ば , 所定軌道への精密投入やフォーメーションフライトに よる観測ミッション, 或いは運用終了後の自主廃棄等が可 能になるという共通認識から, 最近になって关れらの超小 型衛星への搭載を目指した新しい推進系の開発が精力的に 行われている ${ }^{9 \sim 21)}$. Surrey Satellite Technology Ltd. は 2000 年に SNAP-1 によるイソブタンジェットの軌道実証 を行い, 2 〜 km の軌道高度変更と Tsinghua とのランデ ブー実験に成功している ${ }^{6 \sim 8)}$. Swedish Space Coroiration ではコールドガスジェット，MEMSレジストジェット，一 液式スラスタの 3 種類の推進系を搭載した PRISMA の打 上を 2008〜2009 年にも予定している4,14,15). 著者らもま た, 東大阪宇宙開発協同組合 (SOHLA) と共同でパネル 
展開型衛星 (PETSAT) と PETSAT 搭載用推進系の開発 を進め, PETSAT 実証機である SOHLA-2 の 2008 年以降 の打上を目指している3,13) .このように, 2008 年頃からは 推進系を搭載した超小型衛星が次々と登場することが予測 されており，いわば推進系搭載超小型衛星の時代の幕開け である .

今回著者らは, 当研究室の参加した宇宙航空研究開発機構 宇宙科学研究本部 (ISAS/JAXA) の観測ロケット S-31036 号機実験において，積極的な民生品利用 (COTS) を導 入した低価格で手軽に使える推進系の開発を行い, 宇宙環 境での作動実証を行った . 本論文では光の詳細と, 各種試 験結果について報告する。なお，S-310-36での本推進系の 実験目的は次の通りである .

(a) 積極的 COTS を導入した超小型推進系を開発する.

(b)十分な耐環境性を有する推進系を実現する.

(c) 比推力 70 秒程度の推進系を実現する.

(d) 宇宙環境下での作動実証を行う .

\section{S-310-36 と DAU}

S-310-36 ${ }^{22)}$ は, 神戶大学賀谷研究室, 東京大学中須賀 研究室, ウィーン工科大学の共同による宇宙空間におけ るアンテナアレイの構成実験及び各種実験を目的とした ISAS/JAXA 観測ロケットで, 平成 18 年 1 月 22 日 13 時 00 分に上下角 72 度で発射された．発射時の天候は晴れ，地 上風北北東 $7.8 \mathrm{~m} /$ 秒, 気温 $10.2^{\circ} \mathrm{C}$ だった . ロケットは正 常に飛翔し，発射後 80 秒にフェアリング開頭が行われ， 83 秒後に実験装置 (第 1 図) を含む頭胴部を切り離し，姿勢 を安定化させた後，130 秒後に高度 $117 \mathrm{~km}$ でアンテナ展開 動作を開始して，親機 (MOT) から 3 機の子機 (DAU-R， $\mathrm{L} ， \mathrm{~T})$ を射出することで, DAU を頂点とする一辺約 $17 \mathrm{~m}$ の三角形状 (DAU〜MOT 間距離 $10 \mathrm{~m}$ ) の網構造物を展 開した (第 1 図).続いて MOT と DAU を用いた Active Phased Array Antenna 実験を行った . ロケットは発射後
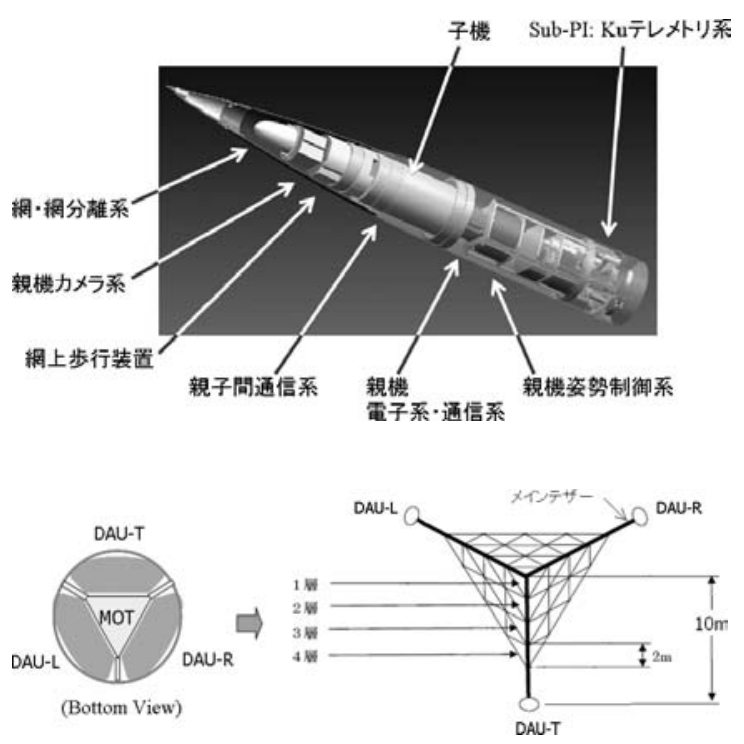

第1図 S-310-36 号機 PI 部構成と網展開
177 秒に最高高度 $127 \mathrm{~km}$ に達した後，計画通り，内之浦 南東海上に落下して実験を終了した。

DAU は設計質量 $5 \mathrm{~kg}$ （実質量 $4 \mathrm{~kg}$ ）であり，DAU 電子 系, リチウムイオン電池, 超小型ホイール, マイクロ波送 受信機, Bluetooth 通信機を含み, 3 機の DAU は頭胴部 内格納位置によって DAU-T, DAU-L, DAU-R などと呼 称が定義される (第 1 図) . DAU-R 及び DAU-L にはコー ルドガスジェット推進系 (DAU-PROP) を搭載している DAU-PROP は積極的な民生品利用 (COTS) を導入した もので, 低価格, 小容積の超小型衛星搭載用推進系の開発 と作動実証の機会とした . 第 2 図にDAU 写真を, 第 3 図 にMOT から射出直後の DAU 写真を示す. DAU-PROP は, DAU 内の所定の容積内 (図中 $140 \mathrm{~mm} \times 132.5 \mathrm{~mm}$ の領域) に収まることが求められた。㚇のため，制限寸法 を遵守しつつ, 民生品と同等性能を有する仕樣変更品の製 作も含めての積極的 COTS とした .

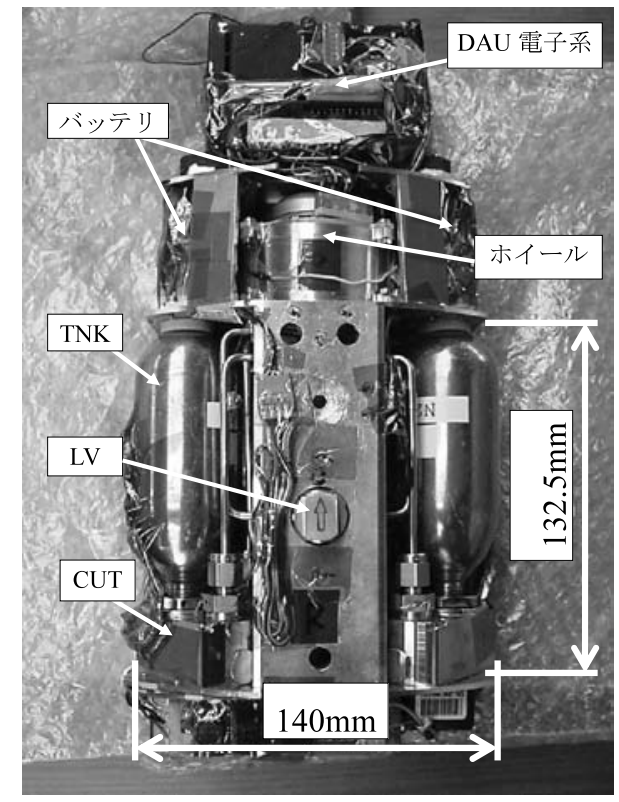

第 2 図 DAU

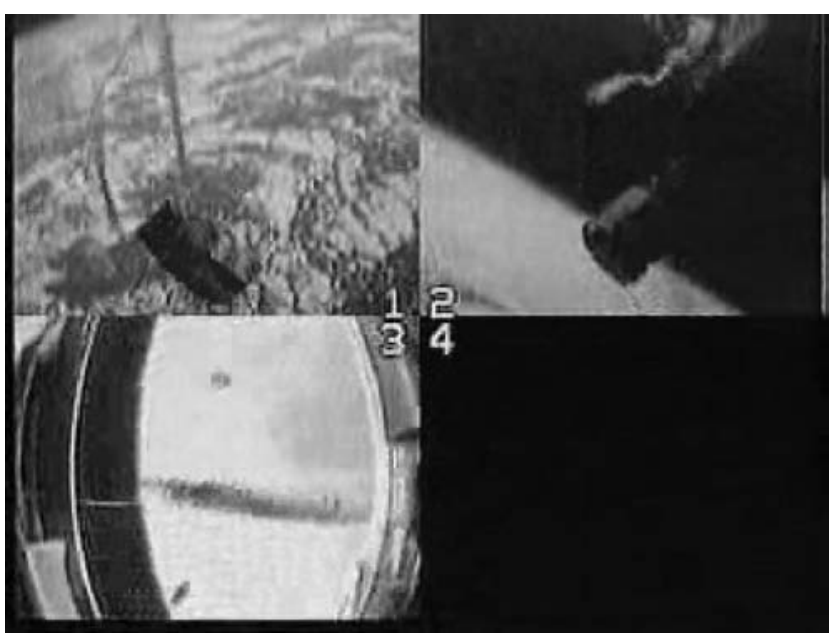

第3 図 射出直後の DAU (左上: DAU-L, 右上: DAU-R, 左下: DAU-T から MOT) 


\section{3. 推 進 系仕 様}

3.1 系統図 第 4 図に, DAU-PROP の系統図を示す DAU-PROP では後述するように, 2 本の高圧ガスタンク (TNK , 約 $18 \mathrm{MPa})$ を搭載し，カットユニット (CUT) 内

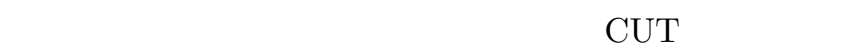
は合流し, 遮断弁 $(\mathrm{LV})$ に到達する. $\mathrm{LV}$ 以前に圧力計 $(\mathrm{PG})$ を配置し，高圧部の圧力を測定することで，推進斉の残量 を推定する.LV の下流で咸圧ユニット (REG) により雰囲 気との差压 $0.2 \mathrm{MPa}$ に調圧される . スラスタ (THR) の作 動はDAUに搭載された電子系によってスラスタ弁 (THV) をPWM 制御または常時開閉することて制御する可変推力 とした .一般に推進性能の取得に不可欠なスラスタチェンバ 内の温度測定は , コールドガスジェットであるため，比較的 理論的取扱が簡単なものであるという前提に立った上で省 略した . 後述する DAU-PROP 要素を組み合わせることで， DAU-PROP 質量は約 $1.5 \mathrm{~kg}$ であった .なお，本論文では すべて, SATP (標準環境温度・圧力 , Standard Ambient Temperature and Pressure) に準じた換算を行っている.

3.2 推力要求 $\mathrm{DAU}$ は, 射出用バネによって $v=1 \mathrm{~m} / \mathrm{s}$ でMOTより射出され，網構造を展開する．網構造を頭胴 部内の収納部より引き出すとき，DAU には減速方向に加 速度か掛かるため, 最大展開位置 (MOT から $10 \mathrm{~m}$ ) まで に減速が行われ, 兴の結果, DAU が最大展開位置で殆ど静 止状態となると見積もられていた．しかしながら万一の場 合を考え，展開時の網構造による減速が全く行われない場 合には, DAU は最大展開位置で網構造物の張力により速 度 $v=1 \mathrm{~m} / \mathrm{s}$ で引き戻される運動をDAU-PROP によって MOT に衝突するまでに静止する必要がある. 推進剤使用 に伴う DAU 質量減少は些少であるとして $M=5 \mathrm{~kg}$ (設計 值) で一定とし，これを一定加速度 $a$ の下， $T$ 秒間で MOT 直前の地点で静止するとすれば，

$$
\left\{\begin{array}{l}
\frac{1}{2} a T^{2}=10 \\
v-a T=0
\end{array}\right.
$$

が成り立ち，これより $T=20$ 秒,$a=0.05 \mathrm{~m} / \mathrm{s}^{2}$ となり， DAU と MOT とが網構造による減速が一切無いとした最 悪条件下でも衝突しないための推力は $F=M a=0.25 \mathrm{~N}$ と求まる.

3.3 搭載推進剂質量 上記の DAU の運動に必要な速度 増分 $\Delta V$ は $1 \mathrm{~m} / \mathrm{s}$ であり，これに必要な推進斉質量は $I_{\mathrm{SP}}$

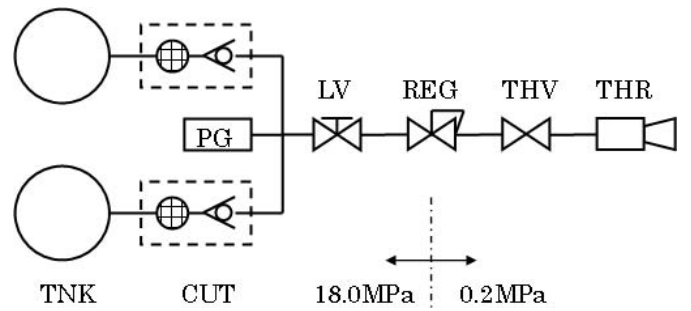

第4図 DAU-PROP 系統図
$=70 \mathrm{~s}$ の場合， $7.27 \mathrm{~g}$ となる. 兴の後，再び DAU を最大 展開位置に移動させるべく噴射を行うが，ここでは上記と 同量を必要と仮定する．更に余裕を持たせるため，更に同 量だけを搭載するものとし，結局 $\Delta V=4 \mathrm{~m} / \mathrm{s}$ を獲得可 能となる有効推進斉質量の下限を $29.0 \mathrm{~g}$ と設定した .ここ で，後述する REG の動作を保証する差圧 $0.2 \mathrm{MPa}$ を維持 可能な推進剂残量をもって有効推進剂質量と定義した .

3.4 性能見積 スラスタの設計仕樣を決めるため, 第 1 表のように幾つかの前提条件を設定して性能見積を行った . 幾つかのノズル開口比 $\varepsilon$ につても計算を行ったが , ここ では $\varepsilon=100, P_{\mathrm{c}}=0.2 \mathrm{MPa}$ の場合について示す.チェ ンバ内温度は標準状態, ノズル効率は代表的な数值を仮定 した .

ノズル出口圧力 $P_{\mathrm{e}}$ を求める .ここでは $\varepsilon$ との関係を用 いる。

$$
\begin{aligned}
\frac{1}{\varepsilon}= & \left(\frac{\kappa+1}{2}\right)^{1 /(\kappa-1)}\left(\frac{P_{\mathrm{e}}}{P_{\mathrm{c}}}\right)^{1 / \kappa} \\
& \times \sqrt{\frac{\kappa+1}{\kappa-1}\left[1-\left(\frac{P_{\mathrm{e}}}{P_{\mathrm{c}}}\right)^{(\kappa-1) / \kappa}\right]}
\end{aligned}
$$

これより， $P_{\mathrm{e}}=5.12 \times 10^{-5}[\mathrm{MPa}]$ と求まり，高度 $120 \mathrm{~km}$ での大気圧 $\left(2.54 \times 10^{-9} \mathrm{MPa}\right)$ より十分大きいのでノズ ル内の流れは壁面から剝離しない . 推力係数 $C_{\mathrm{F}}$ は各点の 圧力と $\varepsilon$ から求まる.

$$
\begin{aligned}
C_{\mathrm{F}}= & \sqrt{\frac{2 \kappa^{2}}{\kappa-1}\left(\frac{2}{\kappa+1}\right)^{(\kappa+1) /(\kappa-1)}\left[1-\left(\frac{P_{\mathrm{e}}}{P_{\mathrm{c}}}\right)^{(\kappa-1) / \kappa}\right]} \\
& +\frac{P_{\mathrm{e}}-P_{\mathrm{a}}}{P_{\mathrm{c}}} \varepsilon
\end{aligned}
$$

$F$ と $P_{\mathrm{c}}$ ，及び $\eta_{\mathrm{n}}$ を用いてスロート径 $D_{\mathrm{t}}$ を求める. 更に, 推進斉流量 $\Delta m$ 及び特性排気速度 $c^{*}$ が求まる.

$$
\begin{aligned}
& A_{\mathrm{t}}=\frac{\pi D_{\mathrm{t}}^{2}}{4}=\frac{F}{\sqrt{\eta_{\mathrm{n}}} C_{\mathrm{F}} P_{\mathrm{c}}} \\
& \Delta m=A_{\mathrm{t}} P_{\mathrm{c}} \sqrt{\frac{\kappa}{R T_{\mathrm{c}}}\left(\frac{2}{\kappa+1}\right)^{(\kappa+1) /(\kappa-1)}}
\end{aligned}
$$

第 1 表 DAU-PROP 仕樣及び推進性能見積

\begin{tabular}{lccc}
\hline \multicolumn{1}{c}{ 項 $\quad$ 目 } & 記号 & 数値 & 単位 \\
\hline 推進剂 & - & $\mathrm{N}_{2}$ & - \\
推進剂の比熱比 & $\kappa$ & 1.400 & - \\
推進剂のガス定数 & $R$ & 0.2968 & $\mathrm{~kJ} / \mathrm{kgK}$ \\
推力要求 & $F$ & 0.25 & $\mathrm{~N}$ \\
チェンバ内温度 & $T_{\mathrm{c}}$ & 298.15 & $\mathrm{~K}$ \\
チェンバ圧 & $P_{\mathrm{c}}$ & 0.20 & $\mathrm{MPa}$ \\
使用時大気圧 (高度 $120 \mathrm{~km}$ ) & $P_{\mathrm{a}}$ & $2.54 \times 10^{-9}$ & $\mathrm{MPa}$ \\
ノズル開口比 & $\varepsilon$ & 100 & - \\
ノズル効率 (仮定) & $\eta_{\mathrm{n}}$ & 0.9 & - \\
ノズル出口圧 & $P_{\mathrm{e}}$ & $5.12 \times 10^{-5}$ & $\mathrm{MPa}$ \\
推力係数 & $C_{\mathrm{F}}$ & 1.75 & - \\
スロート径 & $D_{\mathrm{t}}$ & 1.005 & $\mathrm{~mm}$ \\
推進剂流量 & $\Delta m$ & 0.365 & $\mathrm{~g} / \mathrm{s}$ \\
特性排気速度 & $c^{*}$ & $4.34 \times 10^{2}$ & $\mathrm{~m} / \mathrm{s}$ \\
比推力 & $I_{\mathrm{SP}}$ & 69.8 & $\mathrm{~s}$ \\
\hline
\end{tabular}




$$
c^{*}=\frac{P_{\mathrm{c}} A_{\mathrm{t}}}{\Delta m}
$$

これにより比推力 $I_{\mathrm{SP}}$ を求めることができる.ここでも $\eta_{\mathrm{n}}$ を考慮する。

$$
I_{\mathrm{SP}}=\frac{\sqrt{\eta_{\mathrm{n}}} C_{\mathrm{F}} c^{*}}{g}
$$

以上を䌂めたものを，第 1 表の下部に緒めて記載する .

\section{4. 推進系要素}

4.1 タンク タンク (TNK) には, 日本炭酸瓦斯 (NTG) 社製ミニガスカートリッジを用いた . DAUPROP 搭載領域には, 全高が $132.5 \mathrm{~mm}$ 以下と制限があっ たため, 後述する CUT の大きさを考慮して内容積 $78 \mathrm{ml}$ のもの (第 5 図) を選んだ .ガスカートリッジは SPCE (JIS G3141 $2.1 \mathrm{~mm}$ ) を絞り加工して製造され，外観は 電気亜鉛鍍金 (JIS H8610, Ep-Fe/Zn [2]) 及びクロメー 卜被膜 (JIS H8625，CM2C) を施している.内面は, タ ンク材質の微小剝離によって下流の電磁弁等に悪影響を 及ぼさないよう，無電解ニッケルーリン鍍金 (JIS H8645， ELp- $\mathrm{Fe} / \mathrm{Ni}[1])$ で処理した . 耐圧性能は $54.9 \mathrm{MPa}$ 以上 を保証し，水圧破壊試験により内圧 $60 \mathrm{MPa}$ 付近で破裂， また，内圧 0〜30 MPa 及び雾囲気温度 $-25 \sim 40^{\circ} \mathrm{C}$ での 10 万回を越える繰り返し加圧温度試験の結果，破裂しな かった . ガスカートリッジの蓋部は安全封板て封じられて おり，保管時に規定の内圧及び温度 $\left(100^{\circ} \mathrm{C}\right.$ 以上) を越え た場合には，安全封板に微小な亀裂が発生することでガス を少量ずつ放出する .このガスカートリッジは高圧ガス 保安協会の小型高圧ガス容器認定品であるが, 内容積が $100 \mathrm{ml}$ 未満の容器であり, 更に CUT 内の逆止弁によって ガスカートリッジは孤立するので, 高圧ガス保安法適用除 外に相当し, 同法の一部条項が適用されない，但し，光の 場合には一般高圧ガス保安規則の条項を適用する (第 6 条 第 1 項の十二乃至十三，第 6 条第 2 項第 8 号の八，第 50 条の二，等) .

DAU-PROP 開発に際して，上記のガスカートリッジを 50 本購入した . ガス充填時の 1 本当たりの質量はばらつき があったものの約 $200 \mathrm{~g}$ であった . DAU-PROP では 2 本 を搭載するので, TNK 質量合計は約 $400 \mathrm{~g}$ である . 全数に ついて, $50 \sim 55^{\circ} \mathrm{C}$ において 10 分間の目視による気密検査 と, 水圧試験機による $31.0 \mathrm{MPa}$ を 2 分間維持した耐圧検 査を行い, 問題の無いことを確認した上で窒素ガスを $35^{\circ} \mathrm{C}$

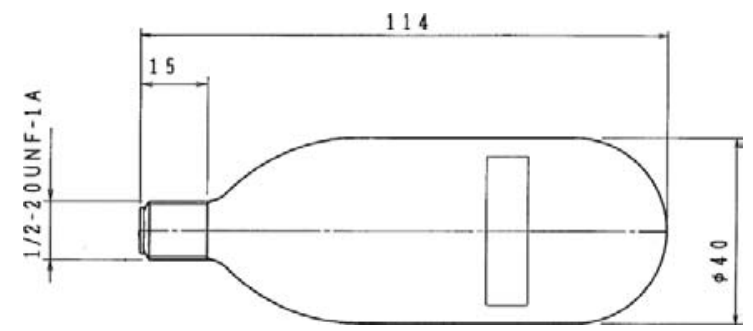

第5図 TNK
の下で $18.6 \mathrm{MPa} て ゙$ 充填した . 従って , 本ガスカートリッ

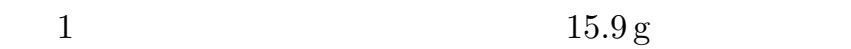
に換算すると $1.40 \times 10^{4} \mathrm{Ncc}$ となる.

打上時の S-310 の振動衝撃環境に TNK が耐え得ること を確認した . まず振動試験機を用いて空の TNK の中心軸 外方向へのモーダル・サーベイを行った (第 6 図). 光の 結果， $450 \mathrm{~Hz}$ 周辺に 1 次モードがあることが分かった（第 7 図) . 一方 , シミュレーションによって 1 次モードを計算 すると $469 \mathrm{~Hz}$ と求まり (第 8 图), 実験值とよく一致し, シミュレーションの妥当性が示された．次に，内圧による 破壞を起こすときのVon-Mises 応力を求める.NTGによ り提供された破壊情報では，内圧 $60 \mathrm{MPa}$ で同体部にて破 断とのことであり，弚の場合の最大 Von-Mises 応力を求め ると胴体部にて $608 \mathrm{MPa}$ と求まった . 高圧ガス保安協会 による小型高圧ガス容器認定規定の内, 容器則第 6 条個別

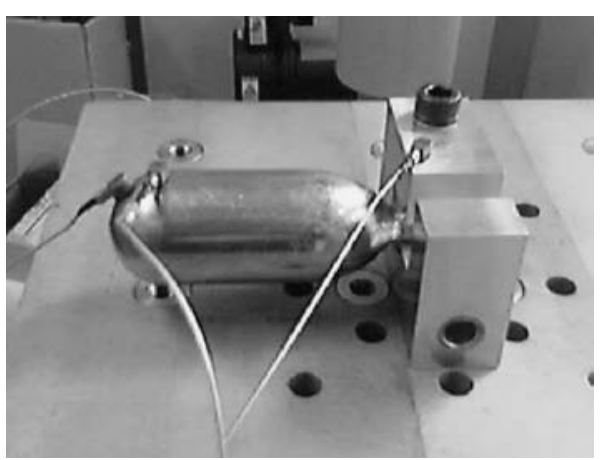

第 6 図 振動試験中の TNK

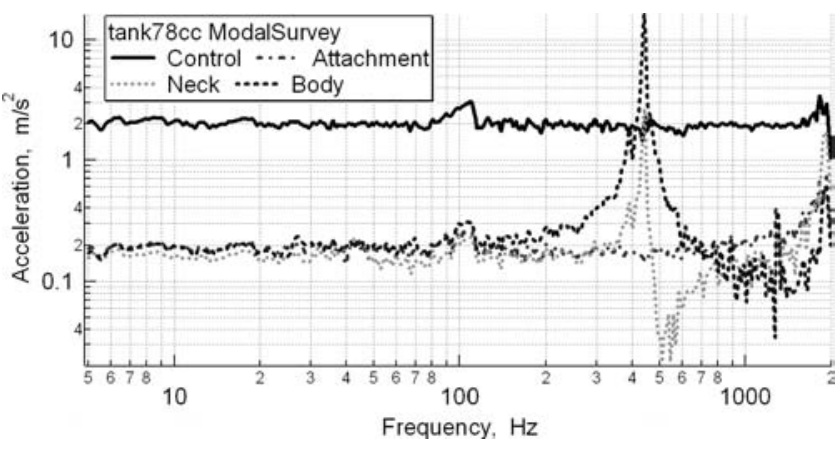

第7図 TNK モーダル・サーベイ結果

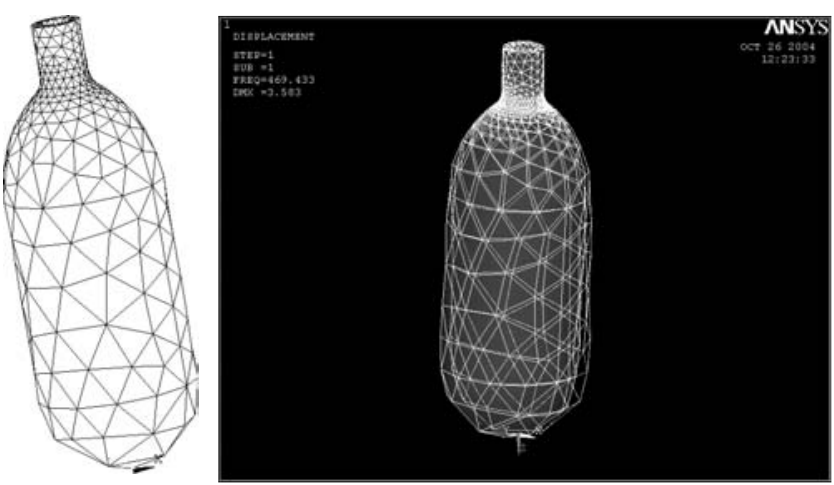

第 8 図 TNK モデルとシミュレーション結果 
通達では，破壊圧力は最大充填圧力の 3 倍以上となってい る. 弚れに準じて, 本推進系開発では打上時の振動衝撃環 境においても安全率 3 を維持するものと定め, 最大許容応 力を $202 \mathrm{MPa}$ とした . 通常の充填圧である内圧 $18.6 \mathrm{MPa}$ 時の Von-Mises 応力は $189 \mathrm{MPa}$ と求まり, 許容範囲であ ることか確かめられた，次に，この充填圧のときに中心軸 方向及び軸外方向に加速度が負荷される場合について計算 を行うと, $300 \mathrm{G}$ 程度であればVon-Mises 応力は殆ど変化 せず, 安全率 3 を維持可能である . $1000 \mathrm{G}$ では $301 \mathrm{MPa}$ となり許容範囲を越えるが，これは実際の打上機において も殆ど起こり得ない，従って，ガスカートリッジは打上環 境に十分耐え得るものと判断した .

4.2 カットユニット 及び減圧ユニット 先述のガスカー トリッジには通常，光の開封と保持を行う取付部と，規定圧 カへの調圧を行う調圧部とが一体となった，NTG 製レギュ レータ NR-14やNR-19 を組み合わせる .これらのリーク 試験はメーカーによって行われており，石䄼水法（検知能 力 $\left.10^{-1} \sim 10^{-3} \mathrm{SCCS}\right)$ により一次圧 $19 \mathrm{MPa}$ 及び $2 \mathrm{MPa}$ の場合においてリークを検知せず，また，放置気密試験に おいて 72 時間ごとに常温 $\rightarrow 0^{\circ} \mathrm{C} \rightarrow 40^{\circ} \mathrm{C}$ と繰り返し温度 変化を行い, 644 時間経過後で $3.5 \times 10^{-6} \mathrm{SCCS}$ 以下との 結果を得ている. NR-14 または NR-19 の取付部は，ガス カートリッジ口金に対応するネジ形状となっており，ガス カートリッジはこのネジ部に捻じ込むことで取り付けられ る .このとき, 取付部に設けられた中空の針よってガス カートリッジの封板が開封される. ガスカートリッジと取 付部の密着面はシール材によってシールされるが, 乥こで リークが起こったとしても，ネジ部のネジ山が高圧で密着 されるため，外部へのリークは抑えられる.ガスカートリッ ジが緩んだ場合でも，ネジ部に設けられた微小穴によって 少量ずつガス抜きが行われる．また，ガスカートリッジ開 封時の切り首流出防止のため, 公称濾過性能 $20 \mu \mathrm{m}$ の焼結 金属エレメントを内蔵している.調圧部にはラプチャ・ディ スクか設けられており，万一内圧が $39 \mathrm{MPa}$ 以上になれば ラプチャ・ディスクが破れてガスを放出するようになって いる .

DAU-PROP においては，搭載領域の全高の制限から TNK にNR-19 を取り付けて組み込むことができなかっ たため, NR-19 と同じ機能と性能を持ちつつ, 取付部と調 圧部とを分離させ，光れ光れカットユニット (CUT) と減 圧ユニット (REG) とすることで, 寸法制限内に収めた（第 9 图) . CUT 及びREG と配管の接続は, Swagelok 社製継 手を用いた . また， 2 本の TNK からのガスが合流するこ

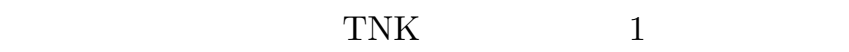
ることを可能とするため, CUT は逆止弁を内蔵している これらの材質は C3604B 及び SUS303 または SUS304 等を 用いており, シール材にはポリウレタン (PUR) やポリア セタール (POM) を用いている $\mathrm{C} 3604 \mathrm{~B}$ の部分にはニッ ケル・クロム鍍金 (JIS H8617，Ep-Cu/Ni5b) を施してい

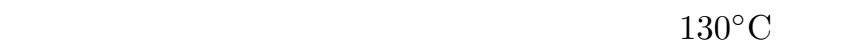
る.この REGにより推進斉供給系は, TNK 内圧が常時負

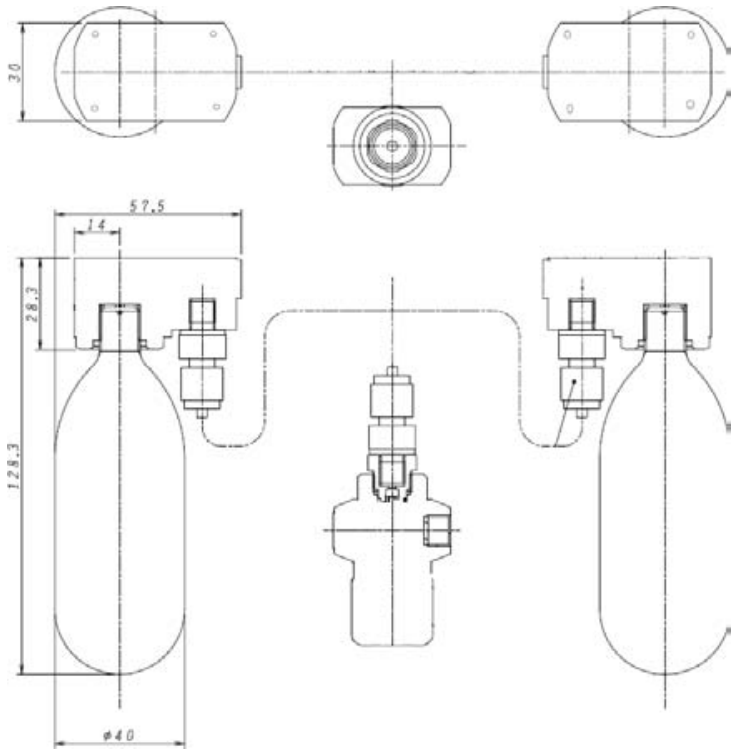

第 9 図 CUT 及び REG

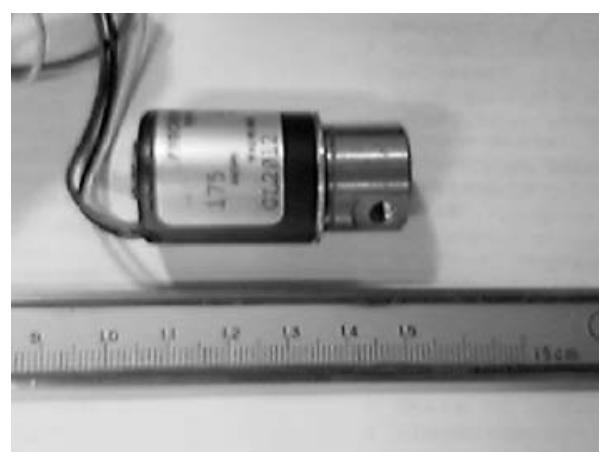

第 10 図 THV

荷される高圧部と，REG の設定圧力以下に負荷される低 圧部とに分けられる.CUT 及びREG の 1 個当たりの質

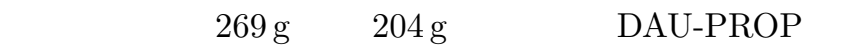
は 2 個の CUT と 1 個の REG を搭載するので, 一式の質 量合計は $742 \mathrm{~g}$ である .

4.3 遮断弁 遮断弁 (LV) には, Swagelok 製手動プラ グ・バルブSS-2P4T-M1 を使用した . 材質は SUS316, 最 高使用圧力は常温で $20.6 \mathrm{MPa}$ であり，約 $4 \times 10^{-9} \mathrm{SCCS}$ 以下のリーク保証がされている . また, Swagelok SC-10 (MS-06-62-SCS-J) に基づく清浄度管理が適用されている。 DAU-PROP では，DAU の外部からアクセスが可能とし つつ, DAU 包絡域の制限から手動ハンドル部分を改良し て組み込んだ (第 2 図参照). 1 個当たりの質量は約 $150 \mathrm{~g}$ であった 。

4.4 スラスタ弁 スラスタ弁 (THV) には, PREDYNE 社製グロメットハウジング構造の通電開型 (N.C.) 電磁弁である GH2015 を採用した (第 10 図). 本体の材質 はSUS303，シール材にはバイトンを選んだ . 使用圧力上限 は約 $0.35 \mathrm{MPa}$ である.接続ポートは 2-way ,\#10-32UNF2Bであり，内部·外部リークについて,ANSI B16.104/FCI 70-2-1976 に基づいた CLASS IV (バブルタイト) が保証 

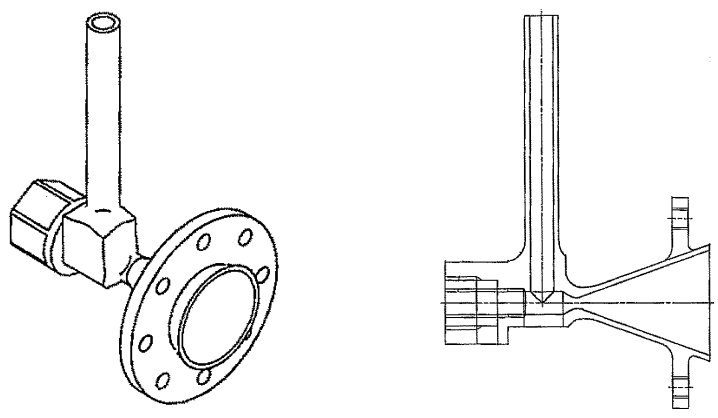

第11図 THR

されている . また , メーカーによる酸素清浄を行っている 定格電圧 $5 \mathrm{~V}$, 定格電力 $2.0 \mathrm{~W}$ ，応答時間は $5 \mathrm{~ms}$ である。 コイル種別は B 種絶縁型であるため, 使用温度上限は約 $130^{\circ} \mathrm{C}$ である.質量は $70 \mathrm{~g}$, オリフィス径は $1.98 \mathrm{~mm}, \mathrm{Cv}$ 值は 0.08 である.

4.5 スラスタ スラスタ (THR) は, IHIェアロスペー スエンジニアリング (ISE) 社による設計・製作を行った（第 11 図). 同社は推進系設計に実績を有しており，光れに基づ いて協議しながらスラスタ及び後述する配管等の開発を行っ た . スラスタの最大予想作動圧力 (MEOP) を $0.45 \mathrm{MPa}$ ， 気密圧力を $0.50 \mathrm{MPa}(\mathrm{MEOP} \times 1.1)$, 耐圧を $0.68 \mathrm{MPa}$ $(\mathrm{MEOP} \times 1.5)$ と設定した . 材質は SUS304 で，スラス タ本体は $4.7 \mathrm{~g}$ （スラスタに付属の配管含む）だった .ノズ ルはコニカル形状であり，収縮部及び拡大部の半頂角は光 れぞれ $30^{\circ}$ 及び $20^{\circ}$ とした . ノズルにはフランジ部を設け， 8 個の穴を開けた . 兴の内の 4 個はDAUに取り付けるた めの固定用穴として用いられ，他の 4 個は密封試験や未使 用時の封栓のための治具を取り付ける補助穴として用いら れる . スロート径については性能見積時の計算値ではなく， 加工精度を考慮して $D_{\mathrm{t}}=1 \mathrm{~mm}$ とする .これにより $F=$ $247 \mathrm{mN}$ となるが, 減少分は些少であるので許容する . ス ラスタチェンバ容積は $0.69 \mathrm{~cm}^{3}$ であり, チェンバ内ガス充 填時間は $4.4 \mathrm{~ms}$ と見積もられる .

4.6 配管·接続部 配管にはすべて, SUS304 製 1/8 イ ンチ管を用いた . SUS 製配管は, 内圧及び打上環境に対す る十分な強度を確保する . 2 本のガスカートリッジからの 合流は溶接によって行い，接合部にはキューブを用いてい る.THVに取り付けられる継手は, Swagelok 社製品にも 適合品があったものの, THV 側のシール性の問題を解決 するために，ISE による設計・製作品を用いてテフロン製 のシール材を介して THV に接続した . THV 周りの接続部 については，圧力測定及びスヌーブ試験を大気圧下で窒素 $0.4 \mathrm{MPa}$ を 600 秒間封入して行った結果, リークを観測し なかった。

4.7 圧力計 DAU 内での DAU-PROP の占有容積の 制限から, 圧力測定は, TNK 内残量と推進剂質量流量と を取得可能な高圧部の一点でのみ行うこととした . 圧力 計 (PG) には，ピエゾ抵抗素子を用いた ICSensors 社製 Model 97 UltraStable を採用した (第 12 図).ハウジング

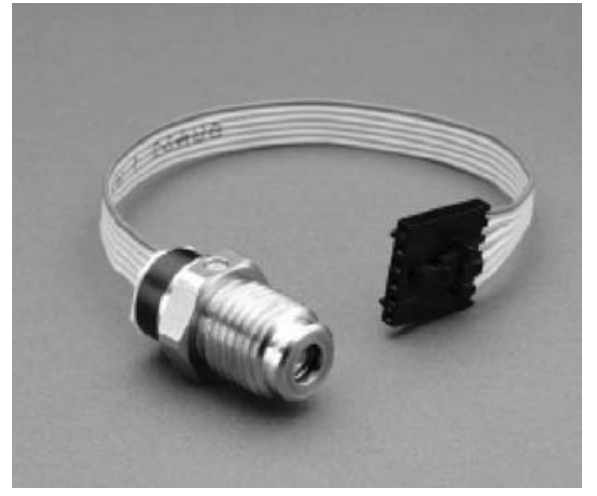

第 12 図 $P G$

材質はSUS316L で，配線やコネクタを含めた重量は $27 \mathrm{~g}$ である . 測定対象圧力は PG の SUS316L 製ダイアフラム に負荷され，PG 内部のシリコンオイルを介してピエゾ抵抗 素子に伝達される.配管との接続部は $1 / 4 \mathrm{NPT}$ ネジとなっ ている.PG は電源 $1.5 \mathrm{~mA}$ 定電流入力によって , 測定範囲 0〜5000 psia の絶対圧に対応したアナログ電圧 0〜100 mV を $\pm 0.25 \%$ 以下の非線形性を保ちつつ出力する . 使用温度 範囲は $-20 \sim 85^{\circ} \mathrm{C}$ とされている. DAU では PG 端子と $\mathrm{DAU}$ 電子系及び電源との接続部は DAU 外部に暴露され ているため，これを用いることで DAU 電子系を起動させ ることなく $\mathrm{PG}$ の外部からの電源供給と出力測定が可能と なり，後述するリーク計測でもこのようにして PGからの 出力を直接計測し，TNK 内ガス残量を取得した．

\section{5. 試験}

5.1 大気中噴射試験 DAU-PROP の作動と, DAU 電 子系の機能確認とを目的として，大気中での噴射試験を 3 回行った . 連続噴射平均時間は $57.6 \mathrm{~s}$ だった . 大気中では ノズル内で流れは剥離していると思われる．一方，スラス タ形状から $\Delta m=0.545 \mathrm{~g} / \mathrm{s}$ と予測され，有効推進斉質量 は $31.2 \mathrm{~g}$ であることから連続噴射時間を見積もると $57.2 \mathrm{~s}$ となり，実際とよく一致している．この試験で, DAU 電子 系の DAU-PROP の制御・計測が正常に行われることを確 認した.

5.2 リーク計測 推進系には, 各種単体試験の終了し た適当な時期に推進剂を充填し，光のままで一定期間を保 管できる十分な内部・外部気密性が要求される．S-310-36 に搭載された DAU-PROP の場合，当初打上予定は 2006 年 1 月となっていたが , 万一この時期の打上が中止となれ ば，半年先への順延もあり得た . 兴こで，S-310-36 の噛合 せが 2005 年夏以後であること，噛合せ以後はフェアリン グの取り外しによって LV の開閉は可能でも頭胴部取り外 しができなければ TNK 交換の機会が無いこと，順延とし て 2006 年夏を想定したことから，LV を閉めた状態で 1 年 間の保管が可能であるものとした .

DAU-PROP の要求では, 必要量の 2 倍である $29.0 \mathrm{~g}$ 以 上の有効推進斉質量を搭載し，最悪ヶースでも $14.5 \mathrm{~g}$ 以上 残存することが求められる.TNK では当初 $31.7 \mathrm{~g}$ の推進 
剂を搭載し，雾囲気圧が非常に小さい場合の有効推進刘質 量は $31.4 \mathrm{~g}$ であり，これが 1 年後に $14.5 \mathrm{~g}$ 以上残存してい ることをリーク量への要求とした . 即ち , 1 年を 365.25 日 とすれば, 許容されるリーク量は $4.74 \times 10^{-4}$ SCCS 以下 となる .

このリーク量は個々の推進系要素単体では十分適合する ものであるが, 各要素を組み合わせた場合には接続部か増 えるため，一般にリーク量か増える．乥こでまず噛合せ前に リーク量を測定する事前リーク計測を行い，もし許容リーク 量を越える場合には継手の増し締めを行う等の対処を行う ものとした .リーク計測は，第 4 図のPG によって , TNK 内圧に一致する高圧部の圧力を計測することで残量を測定 し, 弚の減少量から見積もることで行った . 事前リーク計測 は 2005 年 6 月 1 日 19:00 にガスを再充填してから，2005 年 8 月 22 日 16:25 までの期間で行った (第 13 図). 但し， この期間中は何度か LV を開き, 暫く光のままにしておく (1 回当たりの開時間は最大 5 日間) ということがあった これは, 実際には射場での最終組立後から打上までの間は LV を開いて待機することを模擬したものである. 光の結果， リーク量は DAU-R , DAU-L の炎れ光れについて $2.73 \times$ $10^{-4} \mathrm{SCCS}, 3.27 \times 10^{-4} \mathrm{SCCS}$ であり，これは許容リー ク量よりも小さい. 念のために継手類の増し締めを行った 後, 2005 年 9 月 15 日 3:00 にフライトのための TNK 交 換を行い, 内之浦での最後の組立作業時である 2006 年 1 月 15 日 9:30 まで圧力計の出力を記録した (第 14 図). 光 の結果, リーク量は DAU-R, DAU-L の光れ光れについて $1.72 \times 10^{-4} \mathrm{SCCS}, 2.17 \times 10^{-4} \mathrm{SCCS}$ であり，これは許

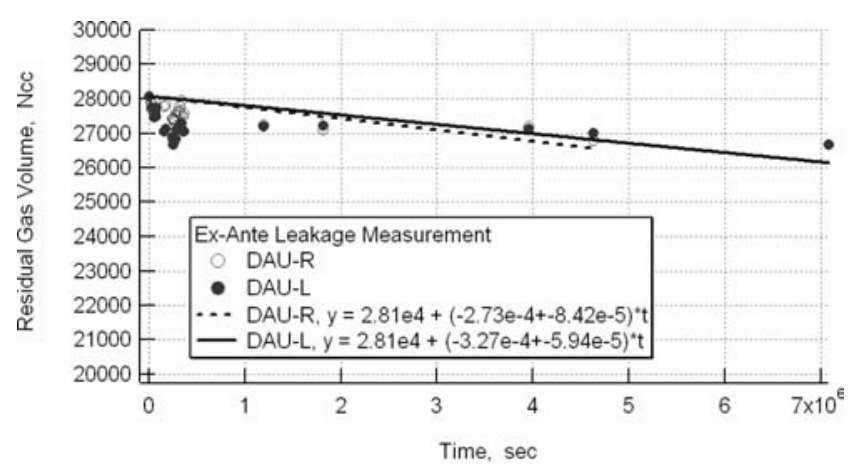

第 13 図 事前リーク試験結果

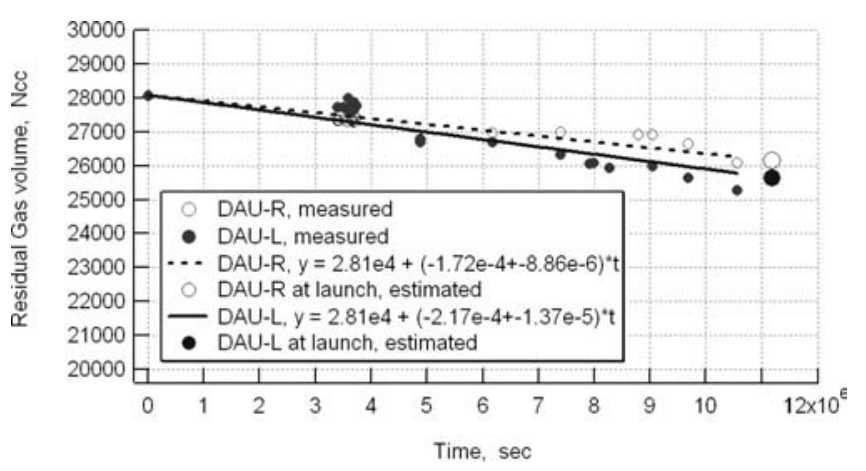

第 14 図 リーク計測結果と打上時残量推定
容リーク量よりも小さい. 事前リーク計測時よりも改善し ているのは, 増し締めの効果と考えられる .

内之浦での最終組立作業後, LV を開とした. 并の後, DAU を含めた搭載機器はフェアリングに覆われるため, 圧 力計の測定はできなかった . 上記のリーク量測定結果を外 挿することにより打上時点 (2006 年 1 月 22 日 13:00) で の残存ガス量を推定すると，DAU-R 及び DAU-L につい て標準体積では $2.62 \times 10^{4} \mathrm{Ncc}$ 及び $2.56 \times 10^{4} \mathrm{Ncc}$, 質 量では $29.5 \pm 0.112 \mathrm{~g}$ 及び $29.0 \pm 0.173 \mathrm{~g}$ と見積もられる .

5.3 推力測定- 真空試験 DAU-PROP について, 推力 校正を行った . 測定は東京大学所有の真空チェンバ内に設 置された振り子式スタンドで行った . 測定はすべて真空チェ ンバ内で行い，噴射前に背圧が 0.1 torr 以下であることを 確認した後に噴射を開始した . THV をとの開閉のDuty 比 $\delta=0.25,0.50,0.75,1.00$ (常時開) として動作させた ときの推力 $F$ を測定した . 噴射中の背圧は $\delta=1.00$ のと き最大となり，1 torr まで上昇した . 谷の結果，第 15 図の ように求められ，各点の測定誤差は 0.6 2.7\%だった . 特 に, Duty 比 1.00 の場合は $F=246 \pm 1.47 \mathrm{mN}$ であり, $D_{\mathrm{t}}$ $=1 \mathrm{~mm}$ とした場合の推力見積と非常によく一致している. これらの離散点から $\delta$ と $F$ の関係を求めると次のように なった

$$
F[\mathrm{mN}]=(240.23 \pm 6.35) \delta, \quad 0<\delta \leq 1
$$

$\delta=1.00$ のときの背圧 $P_{\mathrm{a}}=1$ torr $=1.33 \times 10^{-4} \mathrm{MPa}$ で あり, $P_{\mathrm{e}} / P_{\mathrm{c}}=2.56 \times 10^{-4}$ であることから $P_{\mathrm{e}} / P_{\mathrm{a}}=0.38$ となり, Summerfield Criteria ${ }^{23)}$ 近傍の過膨張となってい る.しかし $\delta$ 小さな場合は光の剝離条件は満たさず $(\delta=$ $0.25,0.50,0.75$ のとき, $P_{\mathrm{a}}=0.3,0.5,0.6$ torr $)$, また , 第 15 図の線形回帰の結果から $\delta=1.00$ 近傍でも線形に $F$ が変化していると推定できることから，DAU-PROP はい

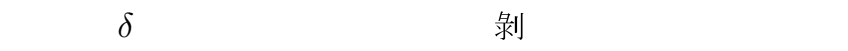
判断した . ノズル出口での負圧を考慮すると $C_{\mathrm{F}}=1.68$, $D_{\mathrm{t}}=1 \mathrm{~mm}$ であることから $\Delta m=0.362 \mathrm{~g} / \mathrm{s}$ なので $c^{*}$ $=434 \mathrm{~m} / \mathrm{s}$, 測定結果より $F=246 \mathrm{mN}$ なので, 以上より $\sqrt{\eta_{\mathrm{n}}}=0.930, I_{\mathrm{SP}}=69.4 \mathrm{~s}$ と求まった .

また，このときに併せて , 1 torr 以下の背圧の下で DAU 電子系を動作させ , 真空チェンバ内外のインタフェースを 介して電子系データをモニタすることで, THV の制御と

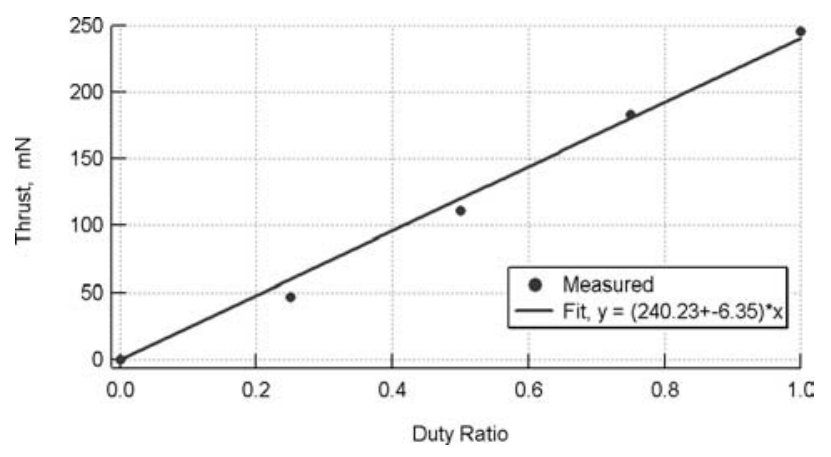

第 15 図 推力測定結果 
PG による測定を含めた DAU 全動作が問題無く行われる ことを確認した .

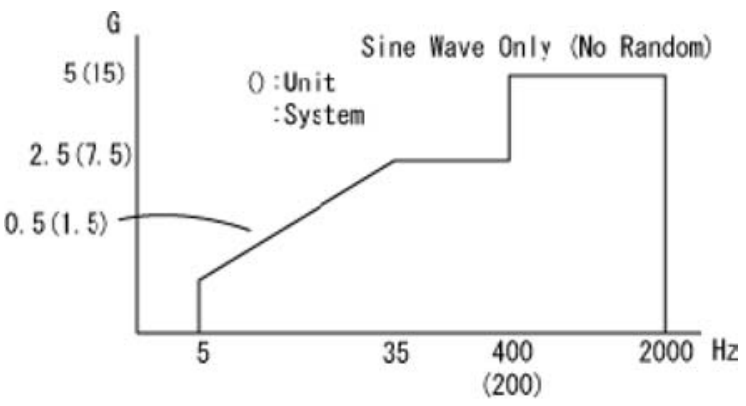

* Shock Test (40G, 10msec) is also required. 第16 図 S-310-36 振動衝撃試験条件

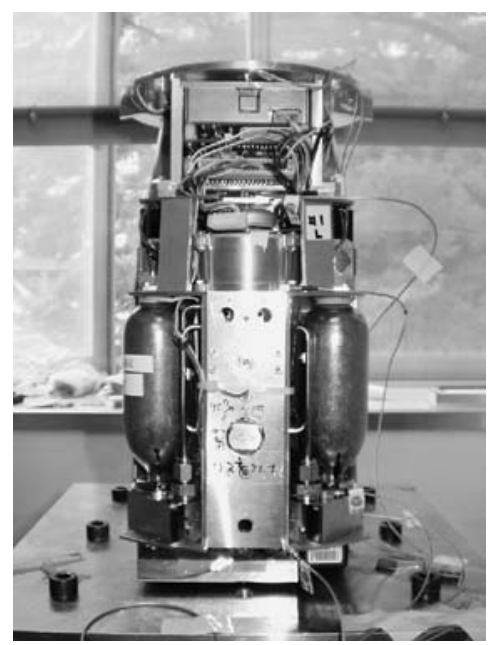

(a) $Z$ 軸

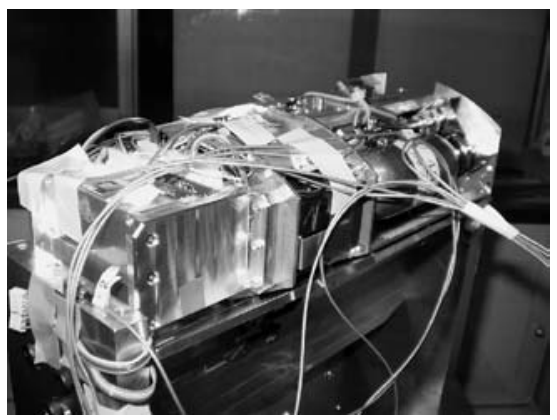

(b) $X$ 軸

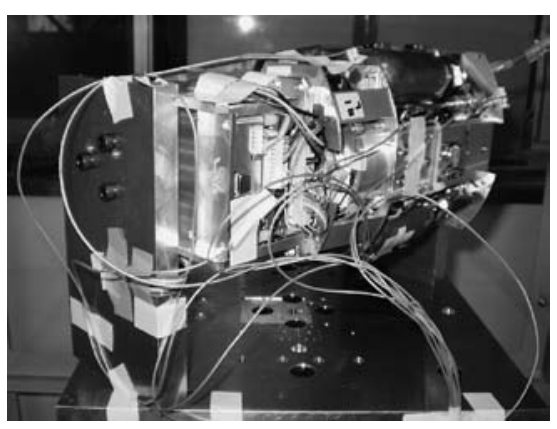

(c) $Y$ 軸

第 17 図振動試験中の DAU
5.4 振動・衝撃試験 DAUにDAU-PROP を搭載した 状態で振動・衝撃試験を行った。振動試験条件は S-310 口 ケットマニュアルに則って要求される第 16 図の単体レベ ル (図中 Unit と記載, 最大 $15 \mathrm{G}$ ) の正弦波, 衝撃試験条 件はピーク值 $40 \mathrm{G}$ で $10 \mathrm{~ms}$ の正弦半波とした . 単体での 振動・衝撃試験は 3 軸について要求されるので, 第 17 図 (a)〜(c)のようにロケット機軸方向 ( $Z$ 軸), 半径方向 ( $X$ 軸)，円周方向 ( $Y$ 軸) の 3 軸について試験を行った。DAU は S-310-36 への実際の搭載と同じようにMOT 構造に取 り付けた . 即ち, DAU は MOT の支持構造と射出用バネ 構造，及び射出を留めるための押さえ具 (射出時はワイヤ カッタにより切断）によって，MOT の支持部分に固定さ れる.このとき押さえ具は，質量 $5 \mathrm{~kg}$ の DAU が $40 \mathrm{G}$ の 加速度を受けても MOTに押さえ付けられるように，DAU を MOT に $200 \mathrm{~kg}$ 以上の力で押さえ付けることを押さえ 具上のひずみゲージにより確認した（実際には DAU 質量 は $4 \mathrm{~kg}$ なので押さえ力は十分である) .また，搭載機器全 体の System レベルでの振動・衙撃試験も行った .これら の振動・衝撃試験のすべてにおいて，DAU-PROP は継手 や TNK の緩み，配管や要素の破損，LV の回転，THV の 不随開放等は一切見られず，また，試験前後のTNK 内圧 の変化も観測されなかった .

5.5 温度環境試験 S-310 ロケットマニュアルに則り， DAU の温度環境試験を行った . DAU を恒温槽に入れて $0 \sim 50^{\circ} \mathrm{C}$ の一定温度に設定し, 十分時間の経過後, 恒温槽 外部から通電を行い，THV の制御と PG による測定が問 題無く行われることを確認した .

\section{6. フライト 解析結果}

S-310-36 のフライト中の搭載機器からの各データは, 頭 胴部から送信される一連のテレメトリとして地上で受信さ れる. 焀の中り DAU-R 及び DAU-L に搭載された PG データ履歴を得た . この履歴は打上 8 分前に電源投入され た時点から始まり，実験終了後，頭胴部が海上に落下しつ つある時点までか記録されていた 。

DAU は，自身に搭載した加速度センサを内部計測系 (INS) に持ち，例えば網展開時に想定以上の減速の加速 度が掛かったときには，弚れを補償するために，タイマ信 号による DAU-PROP 常時噴射開始時刻よりも以前に短時 間の噴射を行うことが可能となっている．

DAU-L の PG 測定履歴は, DAU 射出後, タイマ信号よ りも前に THV を一度開いて, 間もなく閉じた後, タイマ 信号で常時開となっていたが，THV を開いたときに出力 が 0 となり，閉じると再び元の一定の圧力を示すという挙 動不審に陥っていた .この原因は特定されていないが，も し推進系が破損していたとしても出力が瞬時に 0 となるこ とは考えにくいこと，THV の開閉に出力が追随している こと，THV を閉じると瞬時に元の圧力を示すことから，電 気系統もしくはソフトウェア上での不具合であるとも考え られるが, これ以上の解明は不可能であるため，ここでは DAU-L のデータについては詳述しない . 


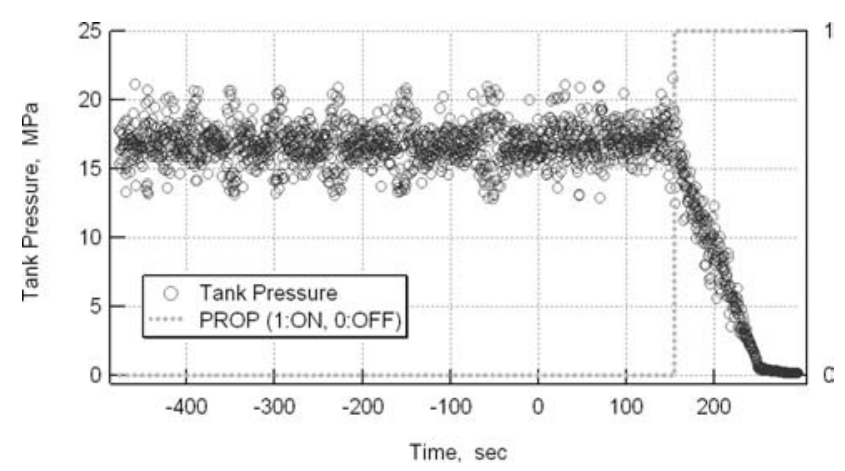

第18図 DAU-R 圧力履歴

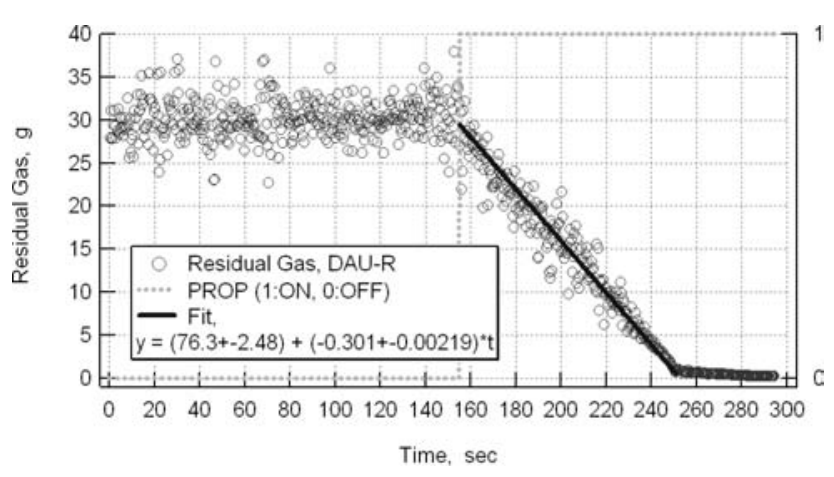

第19 図 DAU-R 推進剂残量履歴
一方，DAU-R では取得周波数 $2.5 \mathrm{~Hz}$ にて正常に $\mathrm{PG}$ 測 定履歴が得られた .これを事前の校正に基づいて圧力值に 換算した履歴を第 18 図に示す. 横軸は打上時刻を 0 として いる. これは正確には DAU-PROP の高圧部の瞬時圧力を 示しているが，ここではTNK 内圧に等しいと仮定した . 打 上 8 分前から打上を挟んで噴射開始までは TNK 内圧の減 少が見られず，これは S-310-36 打上環境において THV の 不適切な開状態やリークが無かったことを示している(こ の点は DAU-L についても当てはまる）．噴射は DAU 射出 後にDAU 自身が判断して行うことはなく，打上後 155 秒 のタイマ信号により THV が常時開となった . 噴射は打上 後 251 秒まで行われたと判断し，噴射時間は $96 \mathrm{~s}$ だった .

打上後 80 秒の時点でフェアリングか開頭し，DAU を含 めた PI 部が宇宙空間に暴露されるが，TNK 内圧はほぼこ の時点から若干の増加を開始し，特にDAU 射出を行った 打上後 133 秒前後からは光れか顕著に見られる. 即ち，打 上時刻までの 476 秒間の平均 TNK 内圧は $16.8 \pm 1.40 \mathrm{MPa}$ であったものが, DAU 分離から噴射開始までの 22 秒間の 平均を見れば $17.6 \pm 1.46 \mathrm{MPa}$ になっている. $\mathrm{PG}$ 出力值の 変動はガウス分布に従うノイズであると仮定し, 両者で $t$ 検定を行った結果，有意水準 $5 \%$ において有意差があると 言える.これは飛翔中のフェアリングの空力加熱やフェア リング開頭後の太陽光の直射による加熱が原因であると考 えられる．DAU-PROP は調圧式であり，レギュレータは 雰囲気圧と二次圧との圧力差を保証しているので㿼度が上 昇しても $P_{\mathrm{c}}=0.2 \mathrm{MPa}$ には変わりないが, $\Delta m$ は減少す る. これらの 2 つの時間範囲における平均 TNK 内圧の増

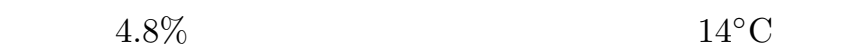
る. 打上時の気温が $10^{\circ} \mathrm{C}$ 程度であり，ロケット内外もま た同程度の温度であったとみなせば，この温度上昇によっ て DAU-PROP 作動時の TNK 内温度は標準環境温度程度 とみなせるので, $\mathrm{PG}$ 出力値を時刻ごとに標準状態へ温度 換算することなくタンク内に残存する推進斉質量に換算し たものを第 19 図に示す.これより推進剂質量流量を求め ると $\Delta m=0.301 \pm 0.00219 \mathrm{~g} / \mathrm{s}$ となる.地上での推力測定 時と変化が無いと考えられる物性值 $(\kappa)$ と形状に基づく パラメータ $\left(A_{\mathrm{t}}, \varepsilon, \eta_{\mathrm{n}}\right)$ を適用して，この $\Delta m$ から比推 力を求めると $I_{\mathrm{SP}}=86.6 \pm 0.629 \mathrm{~s}$ となる.こうして求まっ た $\Delta m$ と $I_{\mathrm{SP}}$ とから $F=256 \pm 2.63 \mathrm{mN}$ と求まり，推力
についてほぼ設計值通りであることが導けるので, フライ トで得られた DAU-R のPG データ履歴は正常に計測され た結果であると判断される。しかしながらこの $I_{\mathrm{SP}}$ は，自 らには加熱機構を有さないコールドガスジェットとしては やや大き過ぎる值である .

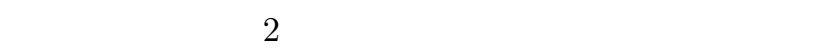
空力加熱や太陽光直射による DAU-PROP 要素の温度上 昇, 引いては推進斉のガスが加熱されていた可能性である . このことは, 先に述べたようにフェアリング開頭前後で平 均 TNK 内圧の増大か観測されていることからも蓋然性が 高い . TNK 内ガス温度が標準温度で一定だと仮定すれば， 予測值として $\Delta m=0.362 \mathrm{~g} / \mathrm{s}, I_{\mathrm{SP}}=72.1 \mathrm{~s}$ が得られる はずであるが, 実際には $\Delta m$ が予測より小さく， $I_{\mathrm{SP}}$ は予 測より大きくなっている．乥こで，フェアリング開頭後も 常に太陽光加熱による温度上昇か続き, ガス温度が 150〜 $160^{\circ} \mathrm{C}$ 程度にまでなったとすれば $\Delta m$ の実測值に整合す る.しかしこの温度上昇は, 通常の日陰から日照へ出たと きの衛星表面温度上昇と比較しても $50 \sim 100^{\circ} \mathrm{C}$ 程度は高い 数值である.もうひとつは, スラスタチェンバ圧がレギュ レータの設定圧力である $0.2 \mathrm{MPa}$ に達していない可能性で ある.即ち，推進剤はREG て調圧された後，一定の流路長 による圧力降下やスラスタチェンバ内に到達するまでのあ る程度の流速増加があれば， $P_{\mathrm{c}}$ がREG の設定圧より小さ くなることが起こり得る.チェンバ内ガス温度か標準状態 であると仮定すれば，フライトから求まった $\Delta m$ から (5) 式を用いて $P_{\mathrm{c}}=0.167 \mathrm{MPa}$ となり，この場合，(6) (7) 式 より $I_{\mathrm{SP}}=72.4 \mathrm{~s}$ となる.

いずれにしても，仕樣上の制約から DAU-PROP には チェンバ内温度・圧力の計測を行っていなかったのでニれ 以上の考察は推定の域を出ないものの, 上記 2 つの要因が 複合的に起こっていた蓋然性が高いと考えられる．また， DAU に搭載した加速度センサの履歴も取得に成功していた が, 他の DAU による網構造物を介しての大きな外乱に埋 もれ，DAU-PROP による加速度を特定できなかった .— 方で, 例え地上試験結果から得られた $I_{\mathrm{SP}}=70 \mathrm{~s}$ しか達成 していないとしても,$F=207 \mathrm{mN}$ であるので, $M=4 \mathrm{~kg}$ の DAU には $a=0.0517 \mathrm{~m} / \mathrm{s}^{2}$ の加速度を与えることがで きるため, 要求は満たしていたと言える .

以上より，比推力の決定には至らなかったものの，少な 
くとも DAU-PROP は打上環境に耐え，正常に電磁弁動作 が行われて圧力測定に成功し，推進系の動作自体はほぼ予 測通りに行われたこと，また，地上試験では比推力 70 秒程 度を達成したことから，積極的 COTS による本推進系の開 発と作動実証は達成したと言える。

\section{7. 結論}

積極的 COTS によるコールドガスジェット推進系を製作 し，下記の事項か確かめられた .

(a) 積極的 COTS を導入して，小容積のコールドガス ジェット推進系を開発した．もし寸法制約が緩ければ，例 えばNTG 製品の内の規格品を用いる等が可能となり，極 めて低価格な推進系を実現できる .

(b) 一般的な超小型衛星の開発スケジュールを鑑みても， バブルタイト保証の電磁弁，非常に小リークの遮断弁等の 採用によって，十分許容され得る範囲内のリーク量に留まっ た。また，打上環境耐性について，高圧タンクや配管等は S-310 の打上環境に耐え得る強度を有し，電磁弁による推 進剂の遮断にも問題無かった .

(c) 地上での真空中推力測定により比推力は 70 秒程度と 求まり，標準的な性能を有するコールドガスジェット推進 系を実現できた .

(d) 軌道上での推進性能は決定できなかったものの，電 磁弁動作とタンク内圧力計測に成功し, 弚れにより正常に 噴射が行われたことから，本推進系の作動実証に成功した と言える .

今回用いたガスカートリッジには $\mathrm{LPG} や \mathrm{CO}_{2}$, 光の他 を規格品として充填可能であるため, 本推進系は異なる推 力範囲でより大きな速度増分を達成する推進系へ転用する ことができる．また，推進系搭載寸法の制約がある程度緩 ければ,レギュレータ等は規格品を使用することができ，光 れにより十分な耐環境性を有する低価格の推進系を実現で きる. 今後更に実際の使用環境に適合する試験や最適化を 行えば, 本推進系を従来品よりも極めて低価格な超小型衛 星搭載用推進系として発展させることが十分可能である .

本推進系の開発を含み，S-310-36 による実験のために経 済的・技術的なご尽力を逐次頂いた稲谷芳文プロジェクト マネージャー，樋口健実験主任，石井信明保安主任を始め とする ISAS/JAXA 関係各位，及び DAU-PROP 搭載に 際して二理解頂いた神戶大学賀谷研究室, 推進系の地上試 験で施設利用を快諾して頂いた東京大学荒川研究室に心よ り感謝する．また，要素開発に当たっては，(株) IHIェア ロスペースエンジニアリング及び日本炭酸瓦斯（株）には， 並々ならぬこ協力を頂いたことを特記する .

\section{参 考 文 献}

1) http://directory.eoportal.org/pres_CubeSatLaunch2.html [cited on April 3, 2007].

2) Sjoberg, F., Clacey, E., Grahn, S., Ljung, B., Rathsman, A. and Rosenqvist, A.: SVEA-An Affordable Small-Size Earth Observation System Based on Recent Advances in Satellite
Engineering, Proceedings of 57th International Astronautical Congress, Valencia, Spain, IAC-06-B1.2.07, 2006.

3) Nakasuka, S., Sugawara, Y., Sahara, H., Koyama, K., Okada, T. and Kobayashi, C.: Panel Extension Satellite (PETSAT) - A Novel Satellite Concept Consisting of Modular, Functional and Plug-In Panels, Proceedings of 1st Workshop on Innovative System Concepts, ESA SP-633, 2006, p. 81.

4) Persson, S. and Jacobsson, B.: PRISMA - Swedish In-Orbit Testbed for Rendezvous and Formation Flying, Proceedings of 57th International Astronautical Congress, Valencia, Spain, IAC-06-D1.2.02, 2006.

5) Enokuchi, A., Nakamura, Y., Funase, R., Nagai, M., Hatsutori, Y., Miyamura, N., Komatsu, M., Yoo, I. Y. and Nakasuka, S.: Technology Demonstration of a New Extensible-Boom-Based Telescope by $5 \mathrm{~kg}$-Class Student Satellite, Small Satellite Systems and Services - The 4S Symposium, Chia Laguna, Italy, 2006.

6) Gibbon, D. and Underwood, C.: Low Cost Butane Propulsion Systems for Small Spacecraft, 15th AIAA/USU Conference on Small Satellites, UT, USA, SSC01-XI-1, 2001.

7) Underwood, C., Richardson, G. and Savignol, J.: SNAP1: A Low Cost Modular COTS-Based Nano-SatelliteDesign, Construction, Launch and Early Operations Phase, 15th AIAA/USU Conference on Small Satellites, UT, USA, SSC01-VI-7, 2001.

8) http://www.ee.surrey.ac.uk/SSC/G7/P6/ [cited on April 3, 2007].

9) Miotti, P., Tajmar, M., Guraya, C., Perennes, F., Marmiroli, B., Soldati, A., Campolo, M., Kappenstein, C. and Eloirdi, R.: Bi-Propellant Micro-Rocket Engine, CANEUS 2004-Conference on Micro-Nano-Technologies, AIAA Paper 2004-6707, 2004.

10) Cardin, J. M., Coste, K., Williamson, D. and Gloyer, P.: A Cold Gas Micro-Propulsion System for CubeSats, 17th AIAA/USU Conference on Small Satellites, Utah, USA, SSC03-XI-8, 2003.

11) Janson, S. W., Helvajian, H., Hansen, W. W. and Lodmell, Lt. J.: Microthrusters for Nanosatellites, 2nd International Conference on Integrated Micro Nanotechnology for Space Applications (MNT99), CA, USA, 1999.

12) Nicolini, D., Robertson, D., Chesta, E., Saccoccia, G., Gibbon, D. and Baker, A.: Xenon Resistojets as Secondary Propulsoin on EP Spacecrafts and Performance Results of Resistojets Using Xenon, Proceedings of 28th International Electric Propulsion Conference, Toulouse, France, IEPC-03305, 2003.

13) Sahara, H., Nakasuka, S. and Kobayashi, C.: Propulsion System on Hydrogen Peroxide Mono-Propellant for Panel ExTension SATellite (PETSAT), Proceedings of 57th International Astronautical Congress, Valencia, Spain, IAC06.C4.1.07, 2006.

14) Gronland, T., Anflo, K. S. and Mollerberg, R.: Green Propulsion for Spacecraft-Towards the First Flight of AND-Based Propulsion on PRISMA in 2008, Proceedings of 57th International Astronautical Congress, Valencia, Spain, IAC06.C4.1.08, 2006.

15) Gronland, T., Rangsten, P., Nese, M. and Lang, M.: Miniaturization of Components and Systems for Space Using MEMS-Technology, Proceedings of 57th International Astronautical Congress, Valencia, Spain, IAC-06.B5.5.12, 2006.

16) Nagase, S., Miyazaki, S., Ayabe, M. and Kohno, M.: A Preliminary Work on HAN/HN-Based Monopropellant, Proceedings of 24th International Symposium on Space Technology and Science, Miyazaki, Japan, ISTS 2004-a-26, 2004.

17) Zube, D. M., Wucherer, E. J. and Reed, B.: Evaluation of HAN-Based Propellant Blends, Proceedings of 39th AIAA/ASME/SAE/ASEE Joint Propulsion Conference and Exhibit, Huntsville, AL, AIAA Paper 2003-4643, 2003.

18) Scharlemann, C., Schiebl, M., Marhold, K., Tajmar, M., 
Miotti, P., Kappenstein, C., Batonneau, Y., Brahmi, R. and Hunter, C.: Development and Test of a Miniature Hydrogen Peroxide Monopropellant Thruster, Proceedings of 42nd AIAA/ASME/SAE/ASEE Joint Propulsion Conference and Exhibit, Sacramento, CA, USA, AIAA Paper 2006-4550, 2006.

19) Barley, S., Palmer, P. and Coxhill, I.: Evaluating the Miniaturisation of a Monopropellant Thruster, Proceedings of 42nd AIAA/ASME/SAE/ASEE Joint Propulsion Conference and Exhibit, Sacramento, CA, USA, AIAA Paper 2006-4549, 2006.

20) Koizumi, H., Inoue, T., Komurasaki, K. and Arakawa, Y.: Development of a Microthruster Using Laser Ignition of Py- rotechnic Pellets, Proceedings of 42nd AIAA/ASME/SAE/ ASEE Joint Propulsion Conference and Exhibit, Sacramento, CA, AIAA Paper 2006-4494, 2006.

21) Rackemann, N., Sanders, B., Vliet, L. and Moerel, J.-L.: Design and Development of a Propulsion System for a CUBESAT, Proceedings of 57th International Astronautical Congress, Valencia, Spain, IAC-06-B5.5.13, 2006.

22）S-310-36 発表文, http://www.jaxa.jp/press/2006/01/ 20060122_s310-36_j.html [cited on April 2, 2007].

23) Kenny, R. J. and Reeves, D. F.: Throttleable Thrustor System, Final Report, JPL Contract No. 952344, Report No. 70.4726.3-28, TRW Systems Group, 1970. 